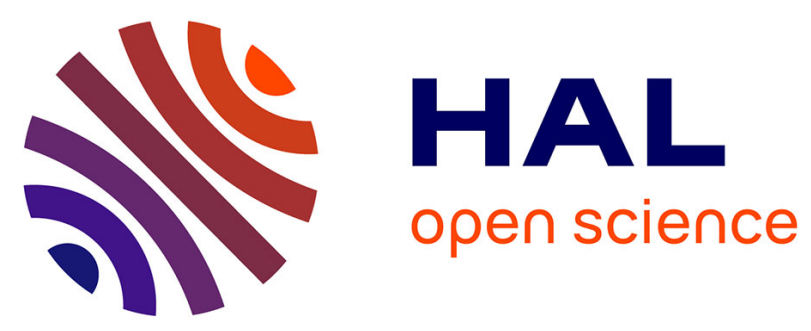

\title{
Characteristics of Non-Allophanic Andisols derived from Low Activity Clay Regoliths in Nilgiri Hills (Southern India)
}

Laurent Caner, G. Bourgeon, François Toutain, A.J. Herbillon

\section{To cite this version:}

Laurent Caner, G. Bourgeon, François Toutain, A.J. Herbillon. Characteristics of Non-Allophanic Andisols derived from Low Activity Clay Regoliths in Nilgiri Hills (Southern India). European Journal of Soil Science, 2000, 51, pp.553-563. hal-00258684

\section{HAL Id: hal-00258684 \\ https://hal.science/hal-00258684}

Submitted on 24 Feb 2008

HAL is a multi-disciplinary open access archive for the deposit and dissemination of scientific research documents, whether they are published or not. The documents may come from teaching and research institutions in France or abroad, or from public or private research centers.
L'archive ouverte pluridisciplinaire HAL, est destinée au dépôt et à la diffusion de documents scientifiques de niveau recherche, publiés ou non, émanant des établissements d'enseignement et de recherche français ou étrangers, des laboratoires publics ou privés. 


\title{
Characteristics of Non-Allophanic Andisols derived from Low Activity Clay Regoliths in Nilgiri Hills (Southern India)
}

\author{
Laurent CANERa,b, Gérard BOURGEONc, François TOUTAINb \\ \& Adrien Jules HERBILLONb
}

\begin{abstract}
Accepted Version: European Journal of Soil Science, 2000, 51, 553-563
\end{abstract}

${ }^{a}$ French Institute of Pondicherry 11, St. Louis Street, P.B. 33, Pondicherry 605 001, India, ${ }^{b}$ Centre de Pédologie Biologique - CNRS, UPR 6831 associée à l'Université Henri Poincaré - Nancy I, B.P. 5, 54501 Vandouvre-Lès-Nancy, France, and ${ }^{\circ} C I R A D-A M I S$ - TA 40/01, 34398 Montpellier cedex 5

\section{Summary}

Low activity clay soils on old planation surfaces of the tropics are generally considered as stable end points of soil formation. It is therefore surprising to find Andosols on them. We characterised the properties of six profiles representative of these soils in the Western part of Nilgiri Hills (2000-2500 m above mean sea level), Southern India, where the present climatic conditions are cool (mean annual temperature $15^{\circ} \mathrm{C}$ ) and humid (mean annual rainfall $2500 \mathrm{~mm})$. Thick $(50-80 \mathrm{~cm})$ dark-reddish brown topsoil overlies strongly desilicated yellowish-red materials. This horizon has andic properties to a sufficient depth and the carbon content requirement of the melanic epipedon to place these soils in the Andisol order. Our data as well as the history of the Nilgiri Hills suggest that the formation of these non-allophanic Andisols result from the succession of two main steps. First, a 'lateritic' weathering cycle led to the relative accumulation of secondary $\mathrm{Al}$ and $\mathrm{Fe}$ oxides. Later, the accumulation of organic matter favoured by a more recent climatic change induced complexation by organic acids of $\mathrm{Al}$ and Fe oxides, and the production of enough metal-humus complexes to give rise to andic properties. Such soils, in which secondary Al 
and $\mathrm{Fe}$ oxides, generally considered as indicators of an advanced weathering stage, are involved in a new cycle of soil formation, are original Andisols.

\section{Introduction}

Since publication of the paper by Garcia-Rodeja et al. (1987), there is growing evidence that 'andic properties' (Soil Survey Staff, 1998) occur in soils that are not derived from volcanic materials. This is the case for some Spodosols in the cold environment of Southern Alaska (Alexander et al., 1993) as well as for genuine Andisols under various temperature and moisture regimes in several parts of the World (Hewitt \& Witty, 1988, Bäumler \& Zech, 1994, Aran et al., 1998). These reports have also progressively made clear that such non-volcanic Andisols (sensu Parfitt \& Clayden, 1991) owe their characteristics properties to metal-humus complexes rather than to allophanes and can thus be called non-allophanic Andisols.

The present work reports the occurrence, in Nilgiri Hills, Southern India, of nonallophanic Andisols derived from a special kind of non-volcanic material consisting of 'laterite', i.e. a low activity clay (LAC) residuum, rich in $\mathrm{Al}$ and Fe oxides. Since such soils and the most common volcanic Andisols are often considered as representing advanced and juvenile stages of soil formation respectively, the occurrence of these soils was unexpected. This paper emphasizes the originality of soils in which secondary oxides, inherited from a previous cycle of soil genesis, appear to play the same role as volcanic glasses do in most Andisols. Moreover, we examine the properties of these particular Andisols and attempt to relate their genesis to the major geologic and climatic events that affected the area

\section{Materials and methods}

\section{Environmental setting}

The Andisols in question are at elevations ranging between 2000 and $2400 \mathrm{~m}$, on the Western part of the Nilgiri Hills (Southern India, Tamil Nadu).

These highlands (also called 'Blue Mountains') are at the junction of Western and Eastern Ghats (Figure 1) and appear as a residual surface edged by steep slopes. Their morphology has been described by Demangeot (1975). The central part, which seems to correspond to an old planation surface, is divided into several basins. Hill ranges, with 


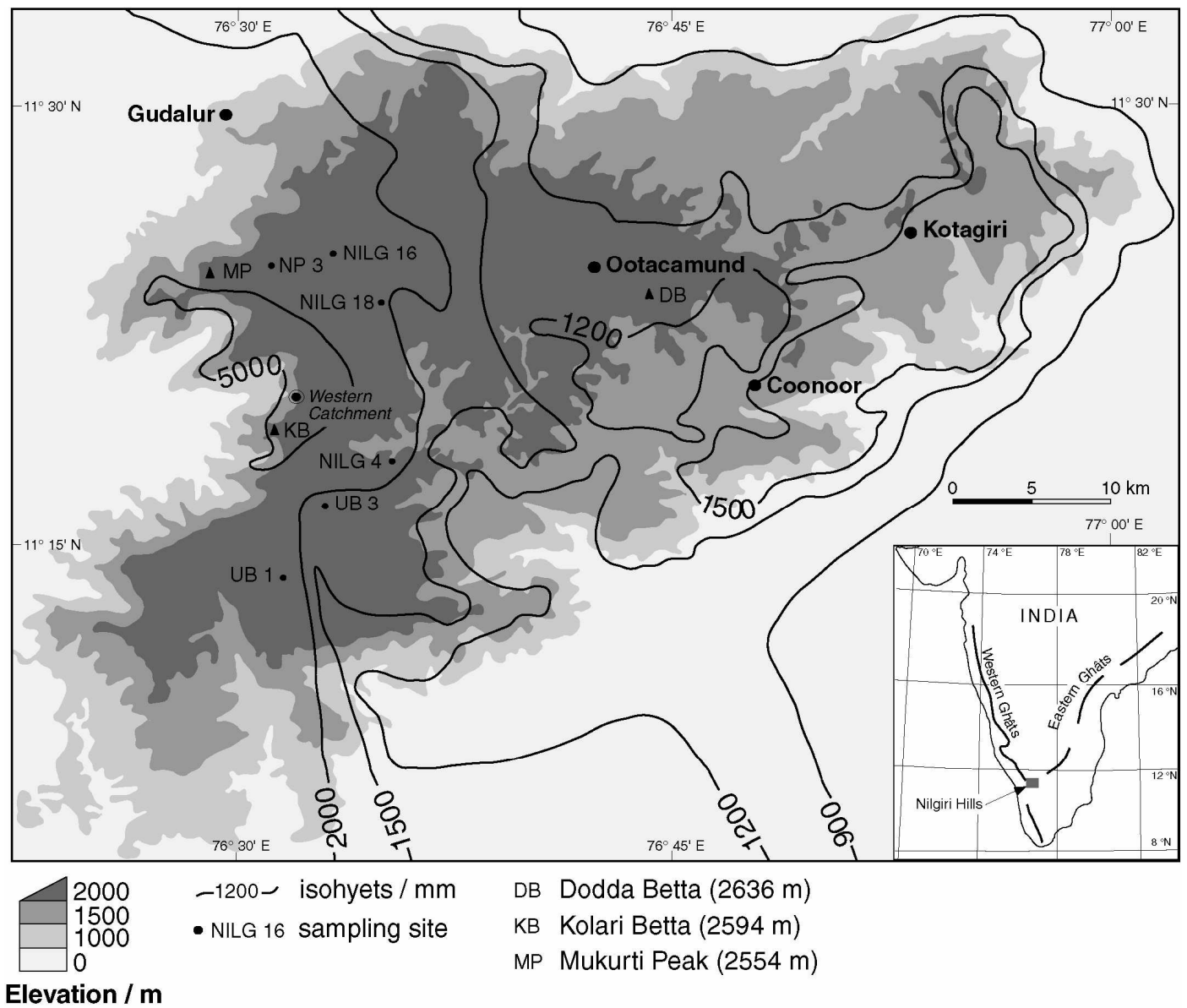

Figure 1: Environmental setting of the Nilgiri Hills and the location of the sampling sites

rounded crests, separate the basins and include the highest points (Dodda Betta, $2636 \mathrm{~m}$; Mukurti Peak 2554 m; Nilgiri Peak 2476 m; Kolari Betta 2594 m), whereas small convex landforms occupy the central parts of the basins.

The bedrock consists of Precambrian charnockites (2.6 Ga). They are hypersthene-bearing granulites dominated by anhydrous silicate minerals ( $\mathrm{K}$ feldspars and $\mathrm{Na}$ plagioclases) resulting from high pressure and high temperature metamorphism. These charnockites are among the hardest and the least porous crystalline rocks of the world and are very resistant to weathering (Gunnell \& Louchet, 2000). Despite the hardness of the rock, the Nilgiri Hills exhibit several decametres of low activity clay regolith, including a few bauxite formations (Subramanian \& Murthy, 1976). However, the weathering front is irregular, and numerous rock outcrops, sometimes forming impressive near-vertical cliffs, are present. The rainfall distribution in the hills is complex due to the interplay of three mechanisms, namely the south-west monsoon, cyclonic disturbances, and convective rain (Von Lengerke, 1977). 
The Western ranges, where we studied the soil, receive $2000-5000 \mathrm{~mm} \mathrm{y}^{-1}$ mainly from south-west monsoon and secondly from convective rain (Table 1,). The length of the dry season was estimated using rainfall data, potential evapotranspiration (PET, Penman formula) and an assumed available soil water capacity of $200 \mathrm{~mm}$. One month was considered to be dry when the sum of rainfall and available soil water reserve was less than $75 \%$ of the PET (Bourgeon, 1988). Based on this calculation, the duration of the dry season is about 2.5 months for the Western region. The frequent mist and fog prevailing on these highlands are also likely to reduce soil moisture losses. At Ootacamund, the main city in the area, the mean annual temperature is $15^{\circ} \mathrm{C}$, with a mean daily minimum of $5^{\circ} \mathrm{C}$ in January and a mean daily maximum of $24^{\circ} \mathrm{C}$ in April.

Two types of native, high-altitude vegetation occur in the area: an evergreen forest, locally called 'Shola' (dominated by Lauraceae, Myrtaceae, and Ericaceae families), and grasslands of varied floristic compositions. Nowadays, due to deforestation and other human activities, the native forest is present only in valleys and on steep slopes, whereas plantations (tea, Acacia, Eucalyptus) and vegetable crops occupy large areas.

\section{Sampling}

Sites for detailed sampling were selected after field observations during which attention focused on soils with deep organic-rich A horizons reported to occur extensively in this area (Oxic Humitropepts of the soil map, Sehgal et al., 1996). A preliminary sampling of their deep A horizons was made to check to what extent the soils could meet the criteria used to define the Andisols order (Soil Survey Staff, 1998). Several profiles exhibited andic properties sufficient to meet the criteria defining the Andic subgroups in several great groups of Soil Taxonomy, but they were not Andisols. In contrast, other profiles were found to belong to the Andisol order, and we selected six of them for this study. They were described using standard horizon designations (Soil Survey Staff, 1998) and each of their genetic horizons was sampled for laboratory analysis. Their locations are shown in Figure 1.

\section{Laboratory methods}

Soil samples were air-dried and passed through a 2-mm sieve before analysis of fine earth. Soil $\mathrm{pH}$ was measured in water and in $1 \mathrm{M} \mathrm{KCl}$ with a soil solution ratio of $1: 2.5$. Organic 
carbon was determined by dry combustion using a Carmograph 8 Wösthoff and a CHN 1108 Carlo-Erba autoanalyser, total nitrogen by Kjeldhal method, cation exchange capacity (CEC) and exchangeable bases by ammonium acetate $(\mathrm{pH} 7)$, and exchangeable Al by $1 \mathrm{M} \mathrm{KCl}$ extraction followed by colorimetry.

Particle size distribution analysis was done using sieving for coarse and fine sand fractions and pipetting for silt and clay. Prior to the analysis, samples were treated with $30 \% \mathrm{H}_{2} \mathrm{O}_{2}$ to destroy organic matter, and with acid ammonium oxalate ( $\left.\mathrm{pH} 3.0\right)$ to remove amorphous cements. Dispersion was made in water with sodium hexametaphosphate by shaking for 16 hours. For profiles NILG 4, NILG 16 and NILG 18, other particle size analyses were done without the acid ammonium oxalate pre-treatment.

We used selective dissolution to identify the different forms of $\mathrm{Al}, \mathrm{Fe}$ and $\mathrm{Si}$ present in the soils. Three extractants were employed: dithionite-citrate-bicarbonate (DCB) (Mehra \& Jackson, 1960) (subscript d); ammonium oxalate (Blakemore et al., 1987) (subscript o); and sodium pyrophosphate (Wada \& Higashi, 1976), (subscript p). The optical density of the oxalate extracts (ODOE) was measured by the method of Daly (1982)

Retention of phosphorus was measured by the method of Blakemore et al. (1987, pp. 44-45), and melanic index was determined following the method of Honna et al. (1988). Bulk density was determined on undisturbed soil samples collected using $100-\mathrm{cm}^{3}$ cylinders

Elemental composition was determined after dissolving $500 \mathrm{mg}$ fine earth in a boiling sulphuric-nitric-hydrochloric acid mixture (triacid digestion). Total reserve in bases (TRB, in $\mathrm{cmol} \mathrm{kg}^{-1}$ ) is the sum of the bases ( $\mathrm{Ca}, \mathrm{Mg}, \mathrm{K}, \mathrm{Na}$ ) dissolved by the triacid digestion.

Mineralogy was assessed from powder X-ray diffraction (XRD) patterns for the different particle-size fractions collected after mechanical separation of soil treated with acid ammonium oxalate. Clay fractions were treated with DCB and examined as oriented clay films by XRD after various chemical and thermal treatments. For some samples, hot $\mathrm{Na}$-citrate extraction was used to allow identification of hydroxy-interlayered-vermiculite (HIV) (Tamura, 1958). Gibbsite content in the clay fraction of the profile NILG 4 was estimated by thermogravimetric analysis using pure gibbsite as a standard. 
Table 1: Environmental conditions and morphological characteristics of selected profiles

\begin{tabular}{|c|c|c|c|c|c|c|c|c|}
\hline Pedon & $\begin{array}{l}\text { Elevation/ } \\
\text { rainfall }\end{array}$ & Vegetation & Horizon & $\begin{array}{l}\begin{array}{l}\text { Depth } \\
(\mathrm{cm})\end{array} \\
\end{array}$ & $\begin{array}{l}\text { color } \\
\text { (moist) }\end{array}$ & $\begin{array}{l}\text { Textural } \\
\text { classes }^{\text {a }}\end{array}$ & Structure & $\begin{array}{l}\text { Clay }^{\mathrm{b}} \\
/ \mathrm{g} \mathrm{kg}^{-1}\end{array}$ \\
\hline \multirow[t]{6}{*}{ NILG 4} & $2100 \mathrm{~m}$ & Forest & & & & & & \\
\hline & $2200 \mathrm{~mm} \mathrm{y}^{-1}$ & & $\mathrm{~A}_{1}$ & $0-30$ & $5 Y R 3 / 2$ & $\mathrm{cl}$ & crumby & 550 \\
\hline & & & $\mathrm{A}_{2}$ & $30-55$ & 5YR $2.5 / 2$ & $\mathrm{cl}$ & massive & 510 \\
\hline & & & $\mathrm{Bw}$ & $55-65$ & $5 Y R 3 / 3$ & sc $g$ & massive & 400 \\
\hline & & & $2 \mathrm{Bo}_{1}$ & $65-110$ & $2.5 Y R 3 / 6$ & $\mathrm{cg}$ & massive & 490 \\
\hline & & & $2 \mathrm{Bo}_{2}$ & $110-150$ & $2.5 Y R 3 / 6$ & $\mathrm{c}$ & massive & 460 \\
\hline \multirow[t]{8}{*}{ NILG 16} & $2100 \mathrm{~m}$ & Tree & & & & & & \\
\hline & $2500 \mathrm{~mm} \mathrm{y}^{-1}$ & plantation & $\mathrm{A}_{1}$ & $0-20$ & 7.5YR 3/2 & $\mathrm{cl}$ & granular fine & 420 \\
\hline & & & $\mathrm{A}_{2}$ & $20-45$ & 5YR $2.5 / 2$ & $\mathrm{cl}$ & massive & 400 \\
\hline & & & $\mathrm{A}_{3}$ & $45-60$ & 5YR $2.5 / 2$ & $\mathrm{cl}$ & massive & 610 \\
\hline & & & $\mathrm{A}_{4}$ & $60-70$ & $5 Y R 3 / 3$ & sc $g$ & massive & 480 \\
\hline & & & $\mathrm{Bw}$ & $70-85$ & $5 Y R 3 / 3$ & $\mathrm{cg}$ & massive & 530 \\
\hline & & & $2 \mathrm{Bo}_{1}$ & $85-100$ & $2.5 Y R 3 / 6$ & c & massive & 670 \\
\hline & & & $2 \mathrm{Bo}_{2}$ & 160 & 10R 4/6 & $\mathrm{c}$ & massive & 760 \\
\hline \multirow[t]{8}{*}{ NILG 18} & $2200 \mathrm{~m}$ & Tree & & & & & & \\
\hline & $2500 \mathrm{~mm} \mathrm{y}^{-1}$ & plantation & $\mathrm{A}_{1}$ & $0-15$ & $5 Y R 3 / 2$ & $\mathrm{cl}$ & granular fine & 580 \\
\hline & & & $\mathrm{A}_{2}$ & $15-35$ & 5YR $2.5 / 2$ & $\mathrm{cl}$ & massive & 590 \\
\hline & & & $\mathrm{A}_{3}$ & $35-60$ & 5YR $2.5 / 2$ & $\mathrm{cl}$ & massive & 600 \\
\hline & & & $\mathrm{A}_{4}$ & $60-80$ & 5YR $2.5 / 2$ & $\mathrm{sc} g$ & massive & 595 \\
\hline & & & $\mathrm{Bw}$ & $80-85$ & 2.5YR 3/4 & $\mathrm{cg}$ & massive & 600 \\
\hline & & & $2 \mathrm{Bo}_{1}$ & $85-95$ & 10R 4/6 & $\mathrm{c}$ & massive & 530 \\
\hline & & & $2 \mathrm{Bo}_{2}$ & $120-140$ & 7.5R 3/8 & c & massive & 510 \\
\hline \multirow[t]{7}{*}{ UB 1} & $2300 \mathrm{~m}$ & Tree & & & & & & \\
\hline & $2200 \mathrm{~mm} \mathrm{y}^{-1}$ & plantation & $\mathrm{A}_{1}$ & $0-20$ & $5 Y R 3 / 2$ & $\mathrm{cl}$ & granular fine & 590 \\
\hline & & & $\mathrm{A}_{2}$ & $20-55$ & 5YR $2.5 / 2$ & $\mathrm{cl}$ & massive & 650 \\
\hline & & & $\mathrm{A}_{3}$ & $55-65$ & $5 Y R 3 / 3$ & sc $g$ & massive & 600 \\
\hline & & & Bw & $65-90$ & 5YR 4/4 & $\mathrm{cg}$ & massive & 630 \\
\hline & & & $2 \mathrm{Bo}_{1}$ & $90-120$ & 5YR 4/6 & $\mathrm{c}$ & massive & 600 \\
\hline & & & $2 \mathrm{Bo}_{2}$ & 160 & 5YR 4/6 & $\mathrm{c}$ & massive & 450 \\
\hline \multirow[t]{6}{*}{ UB 3} & $2350 \mathrm{~m}$ & Savanna & & & & & & \\
\hline & $2300 \mathrm{~mm} \mathrm{y}^{-1}$ & & $\mathrm{~A}_{1}$ & $0-20$ & 5YR $2.5 / 2$ & $\mathrm{cl}$ & granular fine & 585 \\
\hline & & & $\mathrm{A}_{2}$ & $20-40$ & 5YR $2.5 / 2$ & $\mathrm{cl}$ & massive & 530 \\
\hline & & & $\mathrm{A}_{3}$ & $40-60$ & $5 Y R 3 / 3$ & $\mathrm{sc} g$ & massive & 440 \\
\hline & & & $\mathrm{Bw}$ & $60-70$ & $2.5 \mathrm{YR} 4 / 6$ & $\mathrm{cg}$ & massive & 690 \\
\hline & & & 2Bo & 100 & $2.5 \mathrm{YR} 4 / 6$ & $\mathrm{c}$ & massive & 640 \\
\hline \multirow[t]{6}{*}{ NP 3} & $2250 \mathrm{~m}$ & Tree & & & & & & \\
\hline & $2500 \mathrm{~mm} \mathrm{y}^{-1}$ & plantation & $\mathrm{A}_{1}$ & $0-20$ & 5YR $2.5 / 2$ & $\mathrm{cl}$ & granular fine & 560 \\
\hline & & & $\mathrm{A}_{2}$ & $20-50$ & 5YR $2.5 / 2$ & $\mathrm{cl}$ & massive & 580 \\
\hline & & & $\mathrm{A}_{3}$ & $50-80$ & 5YR $2.5 / 2$ & $\mathrm{cl}$ & massive & 640 \\
\hline & & & $\mathrm{Bw}$ & $80-100$ & 5YR 3/2 & sc $g$ & massive & 450 \\
\hline & & & 2Bo & 130 & 5YR 4/6 & $\mathrm{c}$ & massive & 680 \\
\hline
\end{tabular}

${ }^{a}$ Textural classes: sc, sandy clay; c, clay; cl, clay loam; g, gravels

${ }^{\mathrm{b}}$ Clay : content in clay after destruction of organic matter and an oxalate pretreatment 


\section{Results}

\section{Morphological characteristics}

All soil profiles are characterized by the succession of two groups of horizons: darkreddish brown (5 YR 2.5/2 or 5 YR 3/2), organic-rich topsoil above reddish to yellowishred subsurface horizons (Table 1). A 10-cm thick gravelly layer occurs at the transition between these two groups of horizons; it contains 40 to $70 \%$ gravel, mainly ferruginous nodules rounded to irregularly shaped, with thin concentric sesquioxide deposits. In some soils, a few of these gravel particles are white and consist of gibbsite. All horizons are porous to very porous with a considerable microporosity. Boundaries between horizons are smooth.

For three profiles, the particle size distributions obtained with and without acid ammonium oxalate treatment indicate a considerable amount of pseudo-sand particles, especially in the subsoil. We checked that the acid ammonium oxalate pre-treatment destroyed these pseudoparticules: i.e. that coarse sand fraction obtained after this pretreatment comprised mainly quartz particles and small ferruginous nodules.

\section{Chemistry and mineralogy}

The values of the molar ratios, $K_{\mathrm{i}}=\mathrm{SiO}_{2} / \mathrm{Al}_{2} \mathrm{O}_{3}$ and $K_{\mathrm{r}}=\mathrm{SiO}_{2} /\left(\mathrm{Al}_{2} \mathrm{O}_{3}+\mathrm{Fe}_{2} \mathrm{O}_{3}\right)$, and the TRB listed in Table 2 show that the gravel layer forming the transition between the top and the subsurface horizons corresponds, in most cases, to a boundary between horizons characterized by distinctly different weathering stages. The top horizons are indeed generally less desilicated (larger $K_{\mathrm{i}}$ and $K_{\mathrm{r}}$ ) than the subsurface horizons. Similarly, the TRB values (taken here as a weathering index, see Herbillon, 1986) tend to be larger in the surface layers where the $\mathrm{Mg} / \mathrm{TRB}$ ratios are also the largest.

$\mathrm{X}$-ray diffraction data for the silt and clay fractions from profiles NILG 4 and NILG 16 can explain these observations. In all fractions (for an example see Figure 2) the top layers contain indeed less gibbsite than the subsurface horizons. By thermogravimetric analysis of the DCB treated clay fractions of NILG 4 , the gradient in gibbsite was found to be as follows: $330 \mathrm{~g} \mathrm{~kg}^{-1}$ in the $2 \mathrm{~B}_{\mathrm{O} 2}$ horizon, $275 \mathrm{~g} \mathrm{~kg}^{-1}$ in the $\mathrm{B}_{\mathrm{W}}$ horizon and $35 \mathrm{~g} \mathrm{~kg}^{-1}$ only in the $\mathrm{A}_{1}$ horizon. The XRD spectra for the same materials (Figure 2) show also that, as the soil surface is approached and the gibbsite contents decrease, the micas are progressively 
Table 2: Selected chemical properties of the soils

\begin{tabular}{|c|c|c|c|c|c|c|c|c|c|c|c|c|c|c|c|c|c|}
\hline \multirow[t]{3}{*}{ Pedon } & \multirow[t]{3}{*}{ Horizon } & \multirow{3}{*}{$\begin{array}{l}\text { Depth } \\
/ \mathrm{cm} \\
\end{array}$} & Organic & Total & \multicolumn{2}{|c|}{$\mathrm{pH}$} & \multicolumn{4}{|c|}{ Exchangeables bases } & \multirow[t]{2}{*}{$\mathrm{CEC}$} & \multirow[t]{2}{*}{ Exch. Al } & \multirow[t]{3}{*}{$\mathrm{Ki}^{\mathrm{a}}$} & \multirow[t]{3}{*}{$\mathrm{Kr}^{\mathrm{a}}$} & \multirow{3}{*}{$\begin{array}{c}\text { TRB } \\
/ \mathrm{cmol}(+) \\
\mathrm{kg}^{-1}\end{array}$} & \multirow[t]{3}{*}{$\mathrm{K} / \mathrm{TRB}$} & \multirow[t]{3}{*}{$\mathrm{Mg} / \mathrm{TRB}$} \\
\hline & & & $\mathrm{C}$ & $\mathrm{N}$ & \multirow[t]{2}{*}{$\mathrm{H}_{2} \mathrm{O}$} & \multirow[t]{2}{*}{$\mathrm{KCl}$} & $\mathrm{Ca}$ & $\mathrm{Mg}$ & $\mathrm{K}$ & $\mathrm{N}$ & & & & & & & \\
\hline & & & \multicolumn{2}{|c|}{$/ \mathrm{g} \mathrm{kg}^{-1}$} & & & \multicolumn{6}{|c|}{$/ \mathrm{cmol}(+) \mathrm{kg}^{-1}$} & & & & & \\
\hline \multirow{5}{*}{ NILG 4} & $\mathrm{~A}_{1}$ & $0-30$ & 79 & 1.3 & 5.09 & 4.38 & 5.6 & 1.7 & 0.9 & 0 & 35.3 & 3.2 & 1.8 & 1.3 & 72.5 & 0.18 & 0.65 \\
\hline & $\mathrm{A}_{2}$ & $30-55$ & 40 & 2.2 & 4.93 & 4.21 & 0.0 & 0.1 & 0.2 & 0.1 & 24.3 & 2.8 & 1.6 & 1.2 & 70.4 & 0.24 & 0.69 \\
\hline & $\mathrm{Bw}$ & $55-65$ & 21 & 1.0 & 5.01 & 4.35 & 0.1 & 0.1 & 0.2 & 0.1 & 14.3 & 2.6 & 0.9 & 0.6 & 40.6 & 0.31 & 0.59 \\
\hline & $2 \mathrm{Bo}_{1}$ & $65-110$ & 10 & 0.7 & 5.03 & 4.44 & 0.1 & 0.1 & 0.2 & 0.1 & 9.0 & 1.1 & 1.3 & 1.0 & 44.9 & 0.49 & 0.42 \\
\hline & $2 \mathrm{Bo}_{2}$ & $110-150$ & 7 & 0.3 & 5.04 & 4.90 & 0.7 & 0.1 & 0.1 & 0 & 4.3 & 0.7 & 0.9 & 0.7 & 16.3 & 0.49 & 0.36 \\
\hline \multirow[t]{7}{*}{ NILG 16} & $A_{1}$ & $0-20$ & 139 & 8.5 & 4.54 & 4.00 & 0.8 & 0.3 & 0.3 & 0 & 41.3 & 5.1 & 1.4 & 1.0 & 58.2 & 0.17 & 0.81 \\
\hline & $\mathrm{A}_{2}$ & $20-45$ & 82 & 4.8 & 4.85 & 4.41 & 0 & 0 & 0.1 & 0 & 29.3 & 2.4 & 1.2 & 0.9 & 69.1 & 0.17 & 0.78 \\
\hline & $\mathrm{A}_{3}$ & $45-60$ & 40 & 2.6 & 5.37 & 4.47 & 0 & 0.1 & 0.2 & 0 & 26.1 & 0.9 & 1.2 & 0.9 & 89.3 & 0.23 & 0.73 \\
\hline & $\mathrm{A}_{4}$ & $60-70$ & 31 & 1.5 & 5.56 & 4.55 & 0.1 & 0.2 & 0.2 & 0 & 21.2 & 0.6 & 1.0 & 0.7 & 66.5 & 0.25 & 0.72 \\
\hline & $\mathrm{Bw}$ & $70-85$ & 27 & 1.4 & 5.62 & 4.61 & 0.3 & 0.3 & 0.1 & 0 & 17.7 & 0.5 & 0.6 & 0.4 & 49.9 & 0.27 & 0.69 \\
\hline & $2 \mathrm{Bo}_{1}$ & $85-100$ & 6 & 0.6 & 5.75 & 5.91 & 0 & 0 & 0 & 0 & 4.2 & 0 & 0.2 & 0.1 & 21.9 & 0.54 & 0.38 \\
\hline & $2 \mathrm{Bo}_{2}$ & 160 & 3 & 0.5 & 5.89 & 6.26 & 0 & 0 & 0 & 0 & 2.6 & 0 & 0.2 & 0.2 & 25.1 & 0.59 & 0.36 \\
\hline \multirow[t]{7}{*}{ NILG 18} & $A_{1}$ & $0-15$ & 117 & 6.5 & 4.95 & 4.16 & 2.6 & 0.5 & 0.3 & 0 & 35.3 & 2.7 & 1.2 & 0.9 & 59.6 & 0.18 & 0.70 \\
\hline & $\mathrm{A}_{2}$ & $15-35$ & 114 & 5.6 & 4.73 & 4.28 & 0.1 & 0.2 & 0.2 & 0 & 31.8 & 3.1 & 1.4 & 1.0 & 54.4 & 0.19 & 0.73 \\
\hline & $\mathrm{A}_{3}$ & $35-60$ & 53 & 2.4 & 4.90 & 4.51 & 0.0 & 0.1 & 0.1 & 0.2 & 26.2 & 1.3 & 2.1 & 1.4 & 88.5 & 0.17 & 0.80 \\
\hline & $\mathrm{A}_{4}$ & $60-80$ & 22 & 1.1 & 4.91 & 4.49 & 0.9 & 0.4 & 0.1 & 0 & 18.8 & 0.6 & 0.9 & 0.7 & 45.6 & 0.31 & 0.65 \\
\hline & $\mathrm{Bw}$ & $80-85$ & 10 & 0.6 & 4.98 & 4.83 & 0.2 & 0.2 & 0.1 & 0 & 10.4 & 0 & 0.3 & 0.3 & 34.2 & 0.44 & 0.53 \\
\hline & $2 \mathrm{Bo}_{1}$ & $85-95$ & 5 & 0.3 & 5.12 & 5.36 & 0 & 0.1 & 0.1 & 0 & 5.7 & 0.1 & 0.3 & 0.2 & 23.4 & 0.51 & 0.45 \\
\hline & $2 \mathrm{Bo}_{2}$ & $120-140$ & 4 & 0.3 & 5.33 & 5.85 & 0 & 0.1 & 0.1 & 0 & 1.7 & 0.1 & 0.2 & 0.2 & 20.0 & 0.55 & 0.35 \\
\hline \multirow[t]{6}{*}{ UB 1} & $A_{1}$ & $0-20$ & 84 & 5.2 & 4.95 & 4.26 & 5.1 & 1.4 & 0.5 & 0.4 & 22.7 & 2.0 & 3.6 & 1.1 & 68.1 & 0.25 & 0.65 \\
\hline & $\mathrm{A}_{2}$ & $20-55$ & 55 & 3.1 & 4.67 & 4.28 & 0.3 & 0.3 & 0.2 & 0.4 & 22.5 & 3.7 & 1.7 & 1.2 & 82.4 & 0.27 & 0.69 \\
\hline & $\mathrm{A}_{3}$ & $55-65$ & 26 & 1.4 & 4.80 & 4.29 & 1.0 & 0.6 & 0.2 & 0.5 & 15.0 & 2.4 & 1.5 & 1.0 & 89.1 & 0.29 & 0.67 \\
\hline & Bw & $65-90$ & 11 & 0.8 & 5.02 & 4.25 & 1.6 & 0.8 & 0.2 & 0.4 & 10.6 & 1.2 & 1.5 & 1.1 & 79.6 & 0.40 & 0.55 \\
\hline & $2 \mathrm{Bo}_{1}$ & $90-120$ & 10 & 0.8 & 4.99 & 4.66 & 1.7 & 0.9 & 0.2 & 0.3 & 10.0 & 0.2 & 0.5 & 0.6 & 61.4 & 0.38 & 0.56 \\
\hline & $2 \mathrm{Bo}_{2}$ & 160 & 7 & 0.4 & 5.05 & 5.02 & 1.2 & 0.5 & 0.1 & 0.5 & 6.3 & 0 & 0.7 & 0.5 & 26.5 & 0.39 & 0.57 \\
\hline \multirow[t]{5}{*}{ UB 3} & $A_{1}$ & $0-20$ & 156 & 10.1 & 4.74 & 4.12 & 6.0 & 0.6 & 0.6 & 0.5 & 33.2 & 3.5 & 1.9 & 1.2 & 60.7 & 0.24 & 0.58 \\
\hline & $\mathrm{A}_{2}$ & $20-40$ & 83 & 4.8 & 4.52 & 4.32 & 0.2 & 0.1 & 0.3 & 0.3 & 21.0 & 3.0 & 1.4 & 0.9 & 60.8 & 0.26 & 0.68 \\
\hline & $\mathrm{A}_{3}$ & $40-60$ & 21 & 1.1 & 4.67 & 4.44 & 0.2 & 0.1 & 0.2 & 0.4 & 13.4 & 0.9 & 0.9 & 0.6 & 113.4 & 0.58 & 0.39 \\
\hline & $\mathrm{Bw}$ & $60-70$ & 10 & 0.6 & 4.88 & 4.77 & 0.7 & 0.3 & 0.2 & 0.4 & 5.6 & 0.1 & 0.6 & 0.5 & 46.3 & 0.53 & 0.43 \\
\hline & 2Bo & 100 & 6 & 0.5 & 4.76 & 5.76 & 0.3 & 0.1 & 0.1 & 0.6 & 2.4 & 0 & 0.5 & 0.4 & 43.0 & 0.59 & 0.36 \\
\hline NP 3 & $\mathrm{~A}_{1}$ & $0-20$ & 126 & 7.9 & 4.55 & 4.15 & 0.7 & 0.3 & 0.3 & 0.2 & 36.1 & 3.6 & 1.5 & 1.1 & 65.3 & 0.18 & 0.75 \\
\hline & $\mathrm{A}_{2}$ & $20-50$ & 102 & 6.1 & 4.51 & 4.18 & 0 & 0.1 & 0.2 & 0.2 & 29.8 & 4.8 & 1.4 & 1.0 & 64.7 & 0.19 & 0.77 \\
\hline & $\mathrm{A}_{3}$ & $50-80$ & 67 & 4.0 & 4.56 & 4.30 & 0 & 0. & 0.2 & 0.1 & 28.7 & 2.8 & 1.6 & 1.1 & 69.4 & 0.21 & 0.75 \\
\hline & $\mathrm{Bw}$ & $80-100$ & 35 & 1.7 & 4.81 & 4.48 & 0 & 0.1 & 0.1 & 0.2 & 15.4 & 1.2 & 1.2 & 0.7 & 74.7 & 0.28 & 0.69 \\
\hline & 2Bo & 130 & 15 & 0.9 & 4.75 & 4.53 & 0.1 & 0.1 & 0.1 & 0.1 & 10.2 & 0.3 & 0.8 & 0.7 & 79.2 & 0.41 & 0.55 \\
\hline
\end{tabular}

${ }^{\mathrm{a}} \mathrm{Ki}=\mathrm{SiO}_{2} / \mathrm{Al}_{2} \mathrm{O}_{3}$ molar ratio, $\mathrm{Kr}=\mathrm{SiO}_{2} /\left(\mathrm{Al}_{2} \mathrm{O}_{3}+\mathrm{Fe}_{2} \mathrm{O}_{3}\right)$ molar ratio 

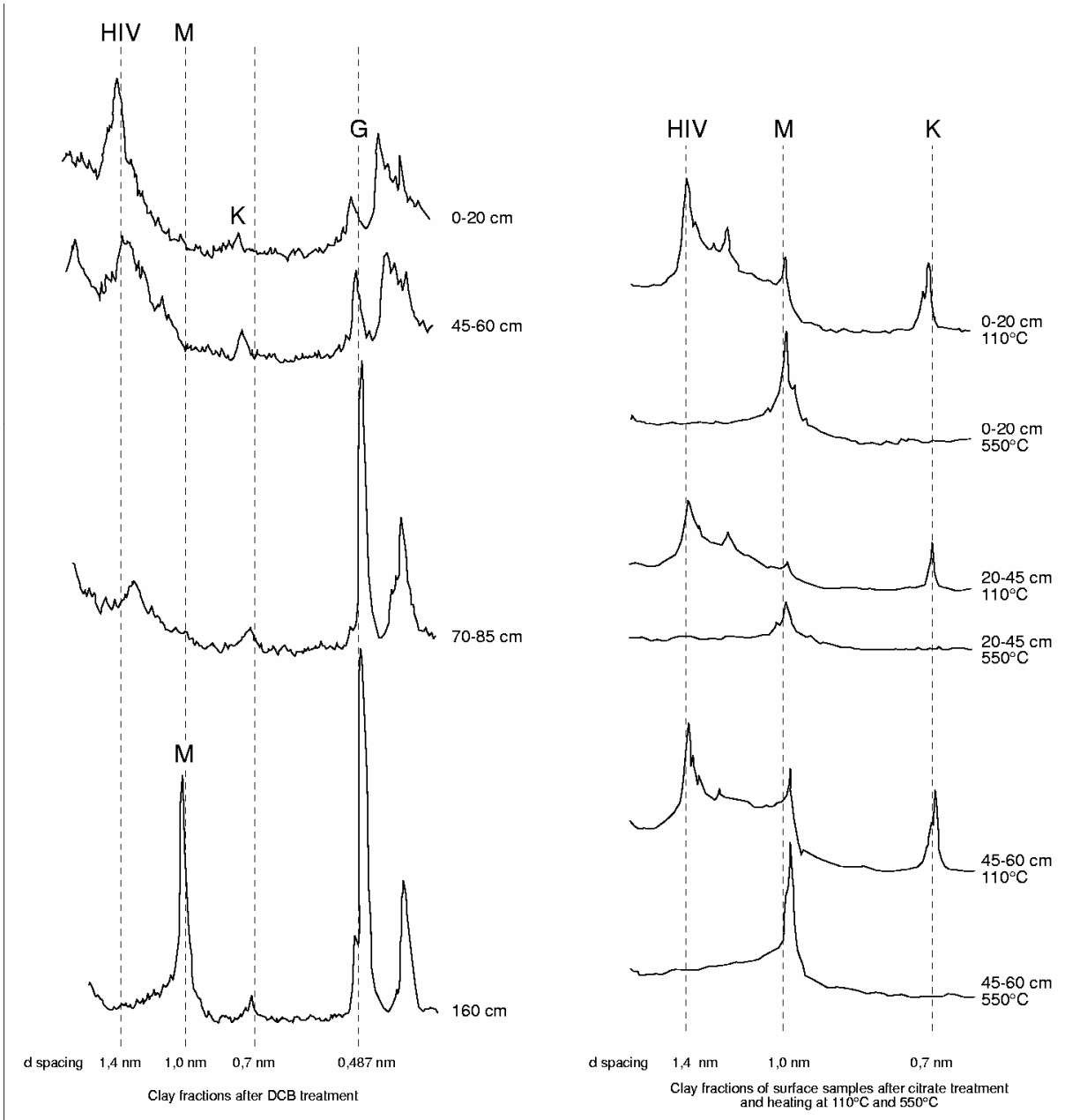

Figure 2: X-ray difraction patterns of clay fractions for the profile NILG 16 (G: gibbsite, HIV: Hydroxy-interlayered Vermiculite, K: kaolinite, M: mica)

transformed into hydroxyaluminium-interlayered-vermiculite (HIV). The K/TRB ratios decreasing towards the surface (Table 2) also accord with this transformation. On the other hand, the XRD spectra of the silt fractions (not shown) indicate that the larger TRB and $\mathrm{Mg} / \mathrm{TRB}$ ratios (Table 2) in the topsoil is linked to the presence of amphibole particles. This $\mathrm{Mg}$-bearing primary mineral was not found in the deep $2 \mathrm{~B}_{\mathrm{O}}$ horizons.

Thus, the available chemical and mineralogical data show that all the profiles have a lithologic discontinuity which, morphologically, is marked by a gravel layer. Below this layer, the materials have a secondary mineral assemblage that can be defined as 'allitic' (i.e. $>180 \mathrm{~g} \mathrm{~kg}^{-1}$ gibbsite). In contrast, in the upper horizons where there is little gibbsite and HIV minerals increase, the assemblage is similar to that defining the kaolinitic mineralogy class of LAC soils. 
Table 2 shows also that the changes in mineralogy with depth are reflected by the surface charge properties of the different horizons. In profiles NILG 16, NILG 18, UB 1 and UB 3, the $2 \mathrm{~B}_{\mathrm{O}}$ horizons have very low ECEC and $\Delta \mathrm{pH}$ values that indicate the presence of positive surface charges. In contrast, the upper horizons are always more acidic, and their $\mathrm{KCl}$-extractable $\mathrm{Al}$ increases towards the soil surface where the occurrence of HIV is most evident (Figure 2)

Other chemical properties are also listed in Table 2. Among them, carbon contents exceeding everywhere a weighted average of $60 \mathrm{~g} \mathrm{~kg}^{-1}$ in the top $50 \mathrm{~cm}$ should be specially noted

\section{Andic properties and soil classifications}

All the data required for the identification of andic properties are shown in Table 3 . All the topsoils have a sufficient thickness with a combination of properties $\left(\mathrm{Al}_{\mathrm{o}}+1 / 2 \mathrm{Fe}_{\mathrm{o}}, \mathrm{P}\right.$ retention, bulk density) required for Andisols. With the exception of the upper A1 horizon of NILG 4, which is the only soil sampled under forest, all horizons exhibiting andic properties have also a melanic index less than 1.7.

Table 3 gives also the names that can be assigned to the profiles (in following the keys proposed according to the World Reference Base (WRB) (FAO, 1998) and the Soil Taxonomy (Soil Survey Staff, 1998). It appears that despite the values of their melanic index, the topsoils of these profile do nt have melanic properties. This is because their (dark-reddish brown) colour reflects better the mineralogy of their iron oxides fraction (identified by XRD as a mixture of goethite and haematite) than the melanic character of their humic constituents.

\section{Selective dissolutions}

The results, including ratios and differences enabling to partition $\mathrm{Al}, \mathrm{Fe}$ and $\mathrm{Si}$ into different forms according to the nature of extractants used (Parfitt \& Childs, 1988), are listed in Table 4. However, as several authors have done earlier, we consider these forms as operational classes of constituents only.

The difference $\left(\mathrm{Fe}_{\mathrm{d}}-\mathrm{Fe}_{\mathrm{o}}\right)$, which is used here to estimate the content of crystalline Fe oxides in the fine earth, increases systematically with depth and is maximum either in the gravel layer or in the horizon immediately below it. Thus, the distribution of crystalline Fe oxides with depth shows some similarities to the distribution of gibbsite and confirms 
Table 3: Andic properties and classification of Nilgiri soils

\begin{tabular}{|c|c|c|c|c|c|c|c|}
\hline Profile & Horizon & $\begin{array}{l}\text { Depth } \\
/ \mathrm{cm}\end{array}$ & $\begin{array}{c}\mathrm{Al}_{\mathrm{o}}+1 / 2 \mathrm{Fe}_{\mathrm{o}} \\
/ \mathrm{g} \mathrm{kg}^{-1}\end{array}$ & $\begin{array}{c}\text { Bulk } \\
\text { density } \\
/ \mathrm{kg} \mathrm{dm}^{-3}\end{array}$ & $\begin{array}{c}\mathrm{P} \\
\text { retention } \\
/ \%\end{array}$ & $\begin{array}{l}\text { Melanic } \\
\text { index }\end{array}$ & Classifications \\
\hline \multirow[t]{5}{*}{ NILG 4} & $\mathrm{~A}_{1}$ & $0-30$ & 26.0 & 0.74 & 97 & 1.92 & Umbri-Pachic \\
\hline & $\mathrm{A}_{2}$ & $30-55$ & 25.2 & 0.89 & 98 & 1.53 & Andosol (acroxic) ${ }^{a}$ \\
\hline & Bw & $55-65$ & 17.1 & - & 85 & - & Acrudoxic \\
\hline & $2 \mathrm{Bo}_{1}$ & $65-110$ & 10.6 & 0.98 & 83 & - & Fulvudand ${ }^{b}$ \\
\hline & $2 \mathrm{Bo}_{2}$ & $110-150$ & 9.3 & - & 83 & - & \\
\hline \multirow[t]{7}{*}{ NILG 16} & $\mathrm{~A}_{1}$ & $0-20$ & 29.5 & 0.47 & 98 & 1.66 & Umbri-Pachic \\
\hline & $\mathrm{A}_{2}$ & $20-45$ & 35.6 & - & 99 & 1.59 & Andosol $^{\mathrm{a}}$ \\
\hline & $\mathrm{A}_{3}$ & $45-60$ & 30.8 & 0.72 & 99 & 1.60 & Pachic Fulvudand ${ }^{\mathrm{b}}$ \\
\hline & $\mathrm{A}_{4}$ & $60-70$ & 25.7 & - & 99 & - & \\
\hline & $\mathrm{Bw}$ & $70-85$ & 23.2 & - & 98 & - & \\
\hline & $2 \mathrm{Bo}_{1}$ & $85-100$ & 7.9 & - & 85 & - & \\
\hline & $2 \mathrm{Bo}_{2}$ & 160 & 9.3 & 1.09 & 96 & - & \\
\hline \multirow[t]{7}{*}{ NILG 18} & $\mathrm{~A}_{1}$ & $0-15$ & 30.2 & 0.78 & 97 & 1.62 & Umbri-Pachic \\
\hline & $\mathrm{A}_{2}$ & $15-35$ & 32.0 & 0.74 & 99 & 1.62 & Andosol $^{\mathrm{a}}$ \\
\hline & $\mathrm{A}_{3}$ & $35-60$ & 30.8 & 0.78 & 99 & 1.73 & Pachic Fulvudand ${ }^{b}$ \\
\hline & $\mathrm{A}_{4}$ & $60-80$ & 21.3 & - & 97 & - & \\
\hline & Bw & $80-85$ & 14.4 & - & 92 & - & \\
\hline & $2 \mathrm{Bo}_{1}$ & $85-95$ & 11.9 & - & 92 & - & \\
\hline & $2 \mathrm{Bo}_{2}$ & $120-140$ & 9.0 & 1.18 & . & - & \\
\hline \multirow[t]{6}{*}{ UB 1} & $\mathrm{~A}_{1}$ & $0-20$ & 22.5 & 0.58 & 93 & 1.60 & Umbri-Pachic \\
\hline & $\mathrm{A}_{2}$ & $20-55$ & 29.4 & - & 95 & 1.60 & Andosol $^{\mathrm{a}}$ \\
\hline & $\mathrm{A}_{3}$ & $55-65$ & 21.3 & 0.77 & 97 & 1.90 & Pachic Fulvudand ${ }^{\mathrm{b}}$ \\
\hline & $\mathrm{Bw}$ & $65-90$ & 14.8 & - & 86 & - & \\
\hline & $2 \mathrm{Bo}_{1}$ & $90-120$ & 15.7 & - & 90 & - & \\
\hline & $2 \mathrm{Bo}_{2}$ & 160 & 10.7 & 1.13 & 76 & - & \\
\hline \multirow[t]{5}{*}{ UB 3} & $\mathrm{~A}_{1}$ & $0-20$ & 24.6 & 0.60 & 94 & 1.62 & Umbri-Pachic \\
\hline & $\mathrm{A}_{2}$ & $20-40$ & 33.6 & - & 99 & 1.51 & Andosol (acroxic) \\
\hline & $\mathrm{A}_{3}$ & $40-60$ & 22.3 & 0.72 & 95 & 1.77 & Acrudoxic \\
\hline & $\mathrm{Bw}$ & $60-70$ & 13.5 & - & 87 & - & Fulvudand ${ }^{b}$ \\
\hline & 2Bo & 100 & 8.9 & 1.05 & 90 & - & \\
\hline \multirow[t]{5}{*}{ NP 3} & $\mathrm{~A}_{1}$ & $0-20$ & 30.5 & 0.44 & 90 & 1.65 & Umbri-Pachic \\
\hline & $\mathrm{A}_{2}$ & $20-50$ & 34.1 & 0.64 & 94 & 1.50 & Andosol $^{\mathrm{a}}$ \\
\hline & $\mathrm{A}_{3}$ & $50-80$ & 30.1 & 0.66 & 99 & 1.73 & Pachic Fulvudand ${ }^{b}$ \\
\hline & Bw & $80-100$ & 23.4 & - & 95 & - & \\
\hline & 2Bo & 130 & 12.4 & 0.89 & 89 & - & \\
\hline
\end{tabular}

${ }^{\mathrm{a}}$ According to WRB (FAO, 1998)

${ }^{\mathrm{b}}$ According to Soil Taxonomy (Soil Survey Staff, 1998)

that the A horizons have less crystalline secondary $\mathrm{Al}$ and Fe oxides than the underlying horizons.

In the A horizons with andic properties, the large $\mathrm{Fe}_{\mathrm{p}} / \mathrm{Fe}_{\mathrm{o}}$ ratios suggest that the iron is present mainly as metal-humus complexes. However, as some $\mathrm{Fe}_{\mathrm{p}} / \mathrm{Fe}_{\mathrm{o}}$ ratios exceed 1, 
Table 4: Data of selective dissolutions procedures

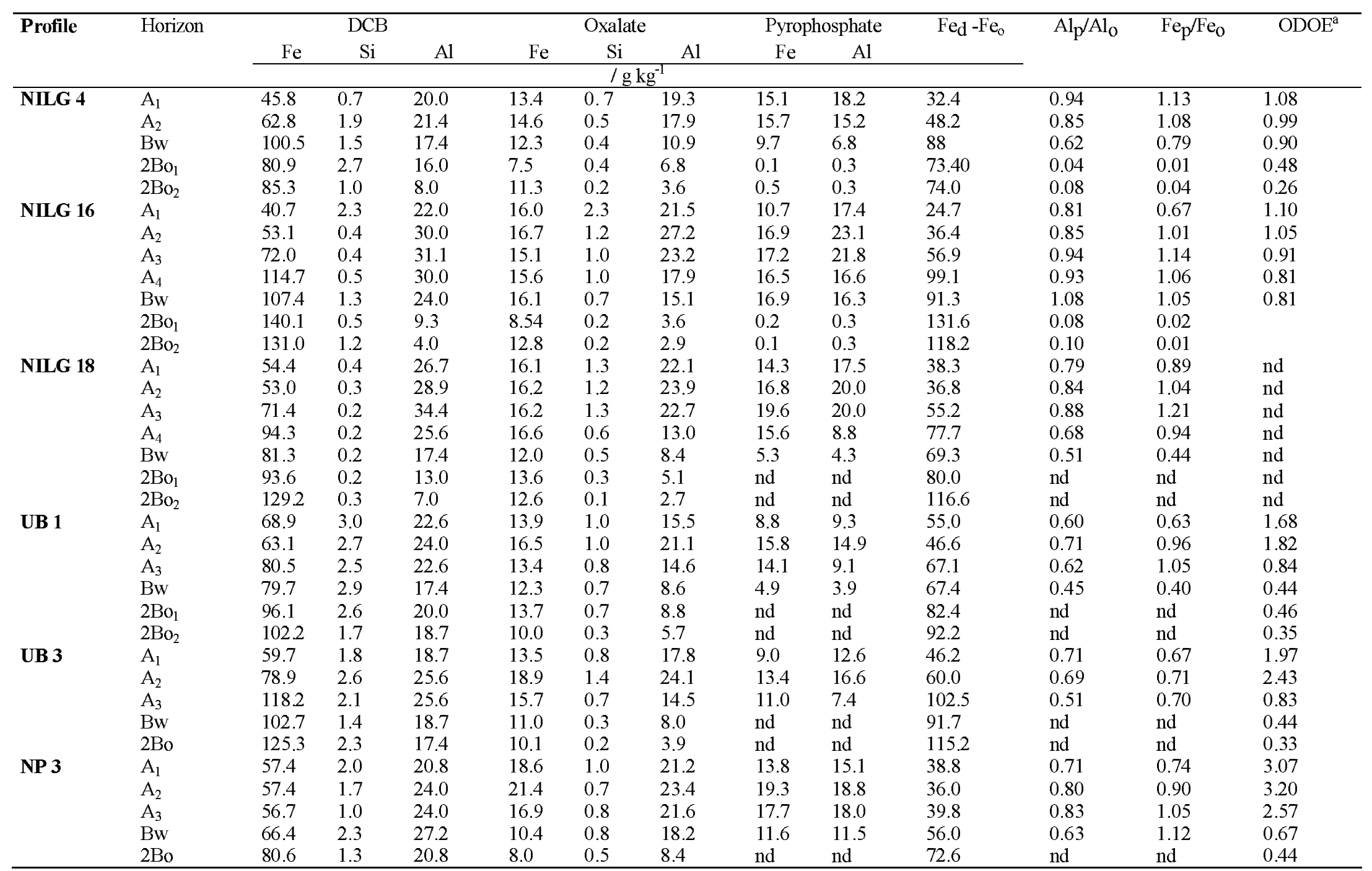

${ }^{a}$ ODOE : Optical density of the oxalate extract measured by the method of Daly (1982) 
we cannot be sure that the pyrophosphate reagent does not disperse also some finely divided crystalline iron oxides (Jeanroy \& Guillet, 1981). In the same horizons, the $\mathrm{Al}_{\mathrm{p}} / \mathrm{Al}_{\mathrm{o}}$ ratio is always larger than 0.5 , and the $\mathrm{Si}_{\mathrm{o}}$ value is less than $6 \mathrm{~g} \mathrm{~kg}^{-1}$ as in the Aluandic horizon of the WRB (FAO, 1998) Thus, Al also is present mainly as metal-humus complexes, and the Andisols of this study can be considered as non-allophanic.

Figure 3 shows that the pyrophosphate-extractable humic substances of the andic horizons have an $\mathrm{Al}$ content similar to that of the non-allophanic horizons $\left(\mathrm{Al}_{\mathrm{p}} / \mathrm{Al}_{\mathrm{o}}>0.5\right.$ and $\mathrm{Si}_{\mathrm{o}}<5 \mathrm{~g} \mathrm{~kg}^{-1}$ ) listed in the Andisol TU database (Nanzyo et al., 1993). As for $\mathrm{Fe}_{\mathrm{p}}$, however, the presence of gibbsite (see Figure 2) suggests that $\mathrm{Al}_{\mathrm{p}}$ might overestimate the Al really involved in metal-humus complexes (Kaiser \& Zech, 1996).

The decrease of the optical density of the oxalate extract (ODOE, Table 3) with depth reveals that cheluviation of metal-humus complexes does not occur in these soils, what accords with their large metal content

\section{Discussion}

\section{Origin of Andisols}

Located on the highest plateaux of Southern India, the Nilgiri Andisols occupy geomorphological positions suggesting that they result from a long and probably complex history. At least two major events are important. The first one, which may have been initiated as early as Eocene (Subramanian \& Mani, 1981), was responsible for the formation of thick regoliths in which gibbsite and iron oxides became important secondary constituents. More recently, possibly after the last climatic change towards cooler conditions in these highlands since about 40000 years B.P. (Sukumar et al., 1993, Rajagopalan et al., 1997), a new cycle of soil formation involving substantial accumulation of organic matter is likely to have been the key process in the development of Andisols.

In the absence of volcanic glasses, and taking also into account the small contents of other primary weatherable minerals even in the least weathered materials above the gravel lines, the development of andic properties in the Nilgiri area results mainly from the interactions between their organic colloids and the oxides inherited from a previous weathering cycle. This hypothesis is supported by: (a) the well known ability of oxide 


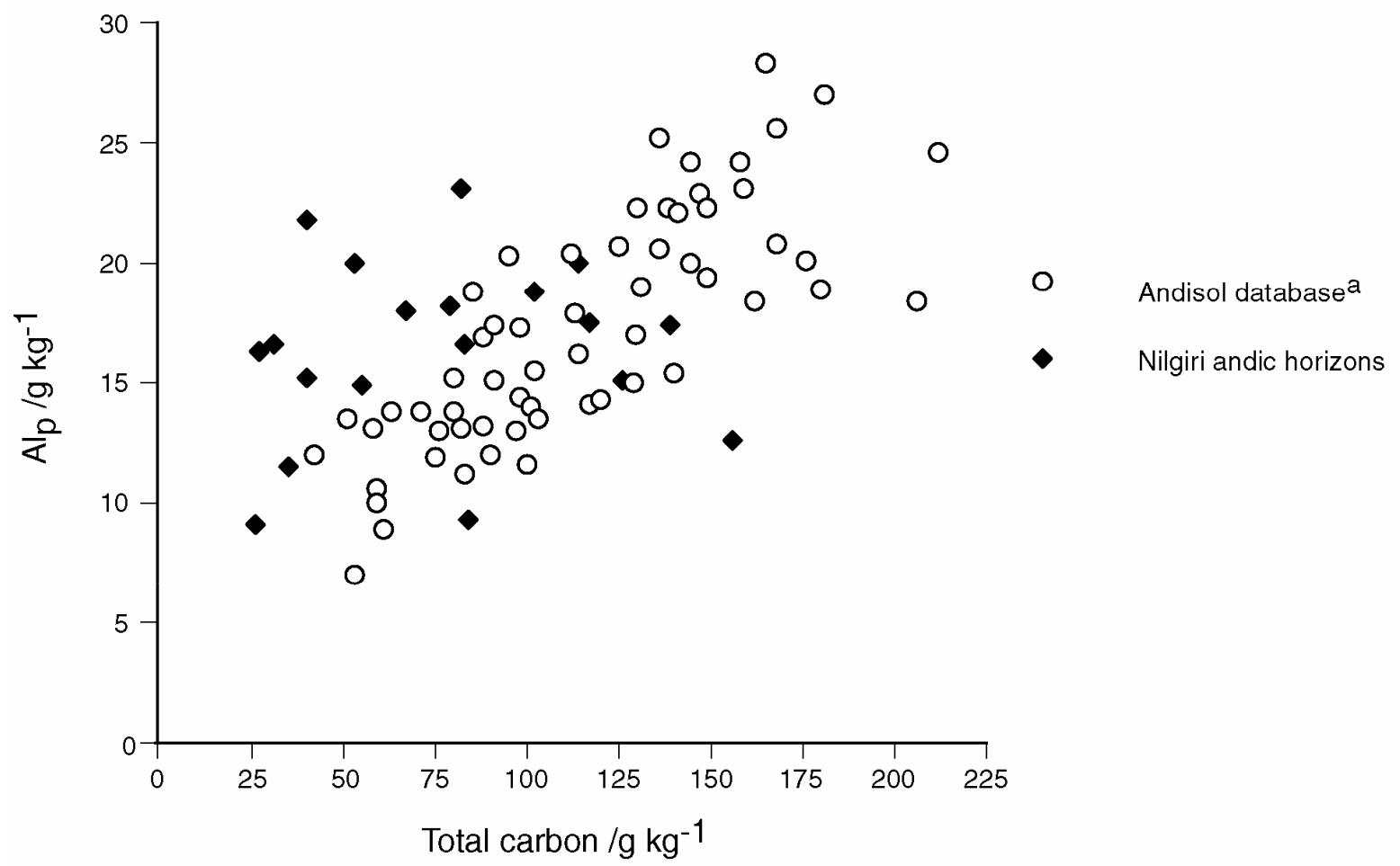

Figure 3: Relation between Alp and total carbon. ${ }^{a}$ data obtained from the TUWAD (Nanzyo et al., 1993) corresponding to A horizons exhibiting andic properties with an udic soil moisture regime, an $\mathrm{Al}_{\mathrm{p}} / \mathrm{Al}_{\mathrm{o}}>0.5$ and an $\mathrm{Si}_{\mathrm{o}}<5 \mathrm{~g} \mathrm{~kg}^{-1}$

surfaces to adsorb and stabilize humic substances (Oades, 1989), and (b) the likelihood that, under acidic conditions (see $\mathrm{pH}$ values in Table 2), this adsorption process is accompanied by the weathering by complexation of small fractions of oxides involved. This last step is in agreement with the observations that the solubility of both gibbsite and crystalline iron oxides may increase by at least two orders of magnitude in the presence of organic acids (see e.g. Chesworth \& Macías, 1985 and the experimental data obtained by Righi et al., 1982).

In the Nilgiri Hills, as in other high-altitude humid environments (Wilke \& Schwertmann, 1977; Madeira \& Furtado, 1987), the mechanisms described above would explain, at least partly, the trend shown by both gibbsite and crystalline iron oxides contents toward decrease near the soil surface and to be minimal where the organic matter contents are at their maximum. On the other hand, a simple calculation shows that the weathering of either $58 \mathrm{~g} \mathrm{~kg}^{-1}$ of gibbsite or $65 \mathrm{~g} \mathrm{~kg}^{-1}$ of goethite (or a combination of sufficient amounts of gibbsite and goethite) can give rise to an $\left(\mathrm{Al}_{\mathrm{o}}+1 / 2 \mathrm{Fe}_{\mathrm{o}}\right)$ value of $20 \mathrm{~g} \mathrm{~kg}^{-1}$ (i.e. the concentration of oxalate-soluble metals defining the andic properties). 
Here, the $K_{\mathrm{i}}$ and $K_{\mathrm{r}}$ values (Table 2) of LAC materials from which the Andisols derive indicate that these amounts represent only small fractions of their oxide contents.

In summary, we propose that the formation of Nilgiri Andisols might result from the succession of the following processes: (a) accumulation of crystalline $\mathrm{Fe}$ and $\mathrm{Al}$ oxides during a former 'lateritic' weathering cycle, and (b) accumulation of organic matter favoured by a climatic change, followed by (c) the weathering by complexation of enough oxides to give rise to the observed andic properties

\section{Conclusions}

The occurrence of Andisols derived from 'lateritic' parent materials shows that several types of $\mathrm{Al}$ and $\mathrm{Fe}-$ bearing minerals enable the development of andic properties. In the Nilgiri Hills these constituents are neither volcanic glasses (Shoji et al., 1993) nor other easily weatherable primary minerals (Garcia-Rodeja et al., 1987), but secondary oxides usually taken as indicators of an advanced weathering stage (Jackson, 1968, Chesworth, 1973). This finding reminds us that, under environmental conditions favouring organic matter accumulation and supplying large amounts of complexing acids, these oxides are no longer stable. They may thus become appropriate sources of metal for metal-humus complexes, i.e. for constituents characteristic of non-allophanic Andisols.

On the other hand, we believe that our findings also have some relevance with respect to the geographical distribution of Andisols on LAC material and of LAC soils showing andic properties. Laterized highlands in cool and humid climates are known in several parts of the tropics. These areas have also been reported to be places where organic matter-rich LAC soils are generally found (Van Wambeke, 1992). These observations suggest that LAC Andisols similar to those described in the present study might have a broader geographical extension than reported so far.

\section{Acknowledgements}

We are indebted to P. Arumugam, K. Balasubramanian and G. Orukaimani from the French Institute of Pondicherry for their help with the soil analysis. We also thank P. Larqué, CGS Strasbourg and F. Lhote, CRPG Nancy who obtained the X-Ray diffraction patterns. J. Ranger from INRA Champenoux helped in the HIV identification. 
Dr Nanzyo from Tohoku University, Japan, is gratefully acknowledged for granting access to TU World Andisol Database. Were are also deeply indebted to the anonymus reviewers for constructive comments.

\section{References}

Alexander, E.B., Shoji, S. \& West, R. 1993. Andic soil properties of Spodosols in nonvolcanic materials of southeast Alaska. Soil Science Society of America Journal, 57, $472-475$.

Aran, D., Gury, M., Zida, M., Jeanroy, E. \& Herbillon, A.J. 1998. Influence de la rochemère et du climat sur les propriétés andiques des sols en région montagnarde tempérée (Vosges, France). European Journal of Soil Science, 49, 269-281.

Bäumler, R. \& Zech, W. 1994. Characterization of Andisols developed from nonvolcanic material in eastern Nepal. Soil Science, 158, 211-217.

Blakemore, L.C., Searle, P.L. \& Daly, B.K. 1987. Methods for Chemical Analysis of Soils. New Zealand Soil Bureau Scientific Report No 80, New Zealand Society of Soil Science, Lower Hutt.

Bourgeon, G. 1988. Esquisse sur les grandes zones de sols du sud de l'Inde. Cahiers ORSTOM, série Pédologie, 24, 303-328.

Chesworth, W. 1973. The parent rock effect in the genesis of soil. Geoderma, 10, 215225 .

Chesworth, W. \& Macías-Vasquez, F. 1985. pE, pH and podzolisation. American Journal of Science, 285, 128-146.

Daly, B.K. 1982. Identification of podzols and podzolised soils in New Zealand by relative absorbance of oxalate extracts of A and B horizons. Geoderma, 28, 29-38.

Demangeot, J. 1975. Recherches géomorphologiques en Inde du Sud. Zeitschrift für Geomorphologie, 19, 3, 229-272

FAO 1998. World Reference Base for Soil Resources. World Soil Resources Reports No 84. FAO, Rome.

Garcia-Rodeja, E., Silva, B.M. \& Macías F. 1987. Andosols developed from non-volcanic materials in Galicia, NW Spain. Journal of Soil Science, 38, 573-591. 
Gunnell, Y. \& Louchet, A. 2000. The influence of rock hardness and divergent weathering on the interpretation of apatite fission track denudation rates. Evidence from charnockites in South India and Sri Lanka. Zeitschrift für Geomorphologie, 44, 33-57.

Herbillon, A.J. 1986. Chemical estimation of weatherable minerals present in the diagnostic horizons of low activity clay soils. In: Proceedings of the Eighth International Soil Classification Workshop: Classification, Characterization and Utilization of Oxisols. Part 1 (eds. F.H. Beinroth, M.N. Camargo, \& H. Eswaran), pp 39-48. EMBRAPA, Rio de Janeiro

Honna, T., Yamamoto, S. \& Matsui, K. 1988. A simple procedure to determine melanic index that is useful for differentiating melanic from fulvic Andisols. Pedologist, 32, 69-78.

Hewitt, A.E. \& Witty, J.E. 1988. Andisol transition with other soils, particularly the Inceptisols. In: Proceedings of the Ninth International Soil Classification Workshop (eds. D.I. Kinloch, S. Shoji, F.H. Beinroth \& H. Eswaran), pp. 233-241. Published by the Japanese Committee for the Ninth International Soil Classification Workshop, for the Soil Management Support Services, Washington, D.C.

Jackson, M.L. 1968. Weathering of primary and secondary minerals in soils. In: Transactions of the Ninth International Congress of Soil Science, Adelaide. Volume 4, pp. 281-292. The International Soil Science Society and Augus and Roberson Ldt. Melbourne.

Jeanroy, E. \& Guillet, B., 1981. The occurrence of suspended ferruginous particles in pyrophosphate extracts of some soil horizons. Geoderma, 26, 95-105.

Kaiser, K. \& Zech, W. 1996. Defects in estimation of aluminum in humus complexes of podzolic soils by pyrophosphate extraction. Soil Science, 161, 452-458.

Madeira, M. \& Furtado, A. 1987. The instability of gibbsite and occurrence of other aluminous products in soils of perhumid climate regions of Portugal. Garcia de Orta, Seria Geologica., 10 , 35-41.

Mehra, O.P. \& Jackson, M.L. 1960. Iron oxide removal from soils and clays by a dithionite-citrate system buffered with sodium bicarbonate. Clays and Clay Minerals, 7, 317-327. 
Nanzyo, M., Dahlgren, R.A. \& Shoji, S. 1993. Chemical characteristics of volcanic ash soils. In: Volcanic Ash Soils. Genesis, Properties and Utilization. (eds. S. Shoji, M. Nanzyo \& R.A. Dahlgren), pp. 145-187. Elsevier, Amsterdam.

Oades, J.M. 1989. An Introduction to organic matter in mineral soils. In: Minerals in Soil Environments, Second Edition (eds. J.B. Dixon, \& S.B. Weed), pp. 89-159. Soil Science Society of America, Madison, WI.

Parfitt, R.L. \& Childs, C.W. 1988. Estimation of forms of $\mathrm{Fe}$ and $\mathrm{Al}$ : a review, and analysis of contrasting soils by dissolution and Mössbauer methods. Australian Journal of Soil Research, 26, 121-144.

Parfitt, R.L. \& Clayden, B. 1991. Andisols - the development of a new order in Soil Taxonomy. Geoderma, 49, 181-198.

Rajagopalan, G., Sukumar, R., Ramesh, R., Pant, R.K. \& Rajagopalan, G. 1997. Late Quaternary vegetational and climatic changes from tropical peats in southern India An extended record up to 40,000 years B.P. Current Science, 73, 60-63

Righi, D., Dupuis, T. \& Girault, P. 1982. Altération expérimentale de gibbsite par des acides fulviques. Conséquences pédologiques pour les sols du plateau de Millevaches. Science du Sol, 2, 145-152.

Sehgal, J.L., Natarajan, P., Reddy P.S.A. \& Dhanapalan Mori A. 1996. Tamil Nadu Soils. National Bureau of Soil Survey and Land Use Planning and the Department of Agriculture of Tamil Nadu, Bangalore.

Shoji, S., Dahlgren, R. \& Nanzyo, M. 1993. Genesis of volcanic ash soils. In : Volcanic Ash Soils. Genesis, Properties and Utilization (eds. S. Shoji, M. Nanzyo \& R.A. Dahlgren) pp. 37-71. Elsevier, Amsterdam.

Soil Survey Staff 1998. Keys to Soil Taxonomy, Eighth Edition. US Department of Agriculture, Washington D.C.

Subramanian, K. S. \& Murthy, M.V.N. 1976. Bauxite and hematite cappings in the Nilgiri - Study from geomorphologic angle. Journal of the Geological Society of India, 17, $353-358$.

Subramanian, K S. \& Mani, G. 1981. Genetic and geomorphic aspects of laterites of high and low landforms in parts of Tamil Nadu, India In: Proceedings of the International Seminar on Laterisation Processes. pp. 237-245. Balkema, Rotterdam. 
Sukumar, R., Ramesh, R., Pant, R.K., \& Rajagopalan, G. 1993. A $\delta^{13}$ C record of late Quaternary climate change from tropical peats in southern India. Nature, London, 364, 703-706.

Tamura, T. 1958. Identification of clay minerals from acid soils. Journal of Soil Science, 9 , 141-147.

Van Wambeke, A. 1992. Soils of the Tropics - Properties and Appraisal. Library of Congress Cataloging-in-Publication Data. McGraw-Hill, New York.

Von Lengerke, H.J. 1977. The Nilgiris - Weather and Climate of a Mountain Area in South India. Volume 32. Beiträge zur Südasienforschung Südasien-Institut. Universität Heidelberg.

Wada, K. \& Higashi, T. 1976. The categories of aluminium- and iron-humus complexes in ando soils determined by selective dissolution. Journal of Soil Science, 27, 357368 .

Wilke, B.M. \& Schwertmann, U. 1977. Gibbsite and halloysite decomposition in strongly acid podzolic soils developed from granitic saprolite of the Bayerischer Wald. Geoderma, 19, 51-61. 